\title{
Experiences and contradictions
}

How the British commemorated the centenary of 1914

Expériences et contradictions: les commemorations du centenaire au Royaume-

Uni en 2014

John Mullen

\section{OpenEdition}

\section{Journals}

\section{Electronic version}

URL: http://journals.openedition.org/rfcb/307

DOI: $10.4000 / \mathrm{rfcb} .307$

ISSN: 2429-4373

Publisher

CRECIB - Centre de recherche et d'études en civilisation britannique

\section{Printed version}

Date of publication: 15 January 2015

ISSN: 0248-9015

\section{Electronic reference}

John Mullen, «Experiences and contradictions », Revue Française de Civilisation Britannique [Online] XX-1 | 2015, Online since 01 May 2015, connection on 30 April 2019. URL : http:// journals.openedition.org/rfcb/307 ; DOI : 10.4000/rfcb.307

This text was automatically generated on 30 April 2019.

Revue française de civilisation britannique est mis à disposition selon les termes de la licence Creative Commons Attribution - Pas d'Utilisation Commerciale - Pas de Modification 4.0 International. 


\title{
Experiences and contradictions
}

\author{
How the British commemorated the centenary of 1914 \\ Expériences et contradictions: les commemorations du centenaire au Royaume- \\ Uni en 2014
}

John Mullen

1 Our issue, "Revisiting the Great War", appears just over six months after the centenary of the outbreak of the conflict, and allows us to assess how this hugely symbolic date was commemorated in the United Kingdom. It was no doubt the largest festival of commemoration Britain had ever seen, with a tremendous variety of events, official and unofficial, militaristic, nostalgic or pacifistic, and it brought to light a number of perhaps unexpected contradictions.

2 A powerful official consensus was proposed concerning the way of marking the centenary, centred around remembering the heroes who died, a consensus particularly necessary for the establishment in the context of the mass opposition to British military policy which has grown up over the last twenty years, notably concerning Iraq and Afghanistan. Indeed, these interventions had seen the development of an anti-war movement in Britain able to bring even more people onto the streets than had the previous anti-war movement of the early 1980s. The movement's highest point was the demonstration of February 2003 against the war in Iraq, ${ }^{1}$ and its passage left campaigners with a permanent organization, the Stop the War Coalition ${ }^{2}$, which has intervened in debates concerning British foreign policy ever since. The existence of this structured anti-war force has allowed activists to challenge more visibly establishment consensus on the First World War.

\section{A political commemoration?}

3 Multiple appeals not to politicize the centenary ${ }^{3}$ seem to have been without real effect. As early as January, the Conservative Education Secretary, Michael Gove, launched an attack on those who, he claimed, were denigrating national heroes. He wrote: 
The First World War may have been a uniquely horrific war, but it was also plainly a just war. [...] The ruthless social Darwinism of the German elites, the pitiless approach they took to occupation, their aggressively expansionist war aims and their scorn for the international order, all made resistance more than justified. ${ }^{4}$

In response, Dan Jarvis, a Labour MP and ex-soldier, carefully chosen as "Labour's lead on the First World War centenary" insisted that Labour should not take a position on whether the war had been justified or not, but should concentrate on ensuring that the centenary was sufficiently inclusive to celebrate the contributions of home front workers (men and women) and others who did not fight, "the miners, factory and railway workers who kept our country going, those who worked the land, and cared for the wounded". ${ }^{5}$

Activists in more radical organizations, such as the Green Party or the Socialist Workers Party, tended to gather behind the Stop the War Coalition and its "No Glory in War" initiative (see below), while in Scotland some debated the relative importance of commemorating the First World War and celebrating the victory of the Scottish at Bannockburn in 1314, a debate reinforced by the imminence of the Scottish independence referendum of September $2014 .{ }^{6}$

6 The flood of commemorative ideas and activities was occasionally accompanied by criticisms of other countries for not doing enough; Germany in particular was singled out. The First World War in Germany has been overshadowed by the memory of the second, and by a generalized distrust of brash patriotism. When Germany's last First World War veteran died in 2008 , he received a fraction of the media coverage accorded to the last “ poilu" or the last Great War "Tommy", who died in 2008 and 2009 respectively. In 2014, it was alleged that Angela Merkel was reluctant to give the centenary of 1914 the importance it was thought to deserve. One Left Party member of the German parliament insisted: "It is scandalous that the federal government is marking the commemoration of the First World War mostly through inaction".

\section{Commerce and celebration}

7 The plethora of British commemorations also attracted considerable criticism from those who wondered whether the tone and intentions were always appropriate. The BBC news website in November published a piece entitled "Does the WW1 tourist trade exploit the memory of the fallen?" Their journalist reported on British visits to Passchendaele site of one of the biggest battles of the war:

On streets teeming with old soldiers and school groups, you can buy T-shirts proclaiming "I'm a Battlefield Relic", teddy bears in tin hats, and, perhaps most cynically, Passchendaele lager. "When opening the bottle, please hold a minute of silence to commemorate those who fell on the battlefield," says the label. ${ }^{9}$

While Simon Jenkins in The Guardian complained:

Britain's commemoration of the Great War has lost all sense of proportion. It has become a media theme park, an indigestible cross between Downton Abbey and a horror movie. I cannot walk down the street or turn on the television without being bombarded by Great War diaries, poems, scrapbooks and songs. The BBC has gone war mad. We have Great War plays, Great War proms, Great War bake-ins, Great War gardens... There is the Great War and the Commonwealth, the Great War and feminism, Great War fashion shows and souvenirs. There are reportedly 8,000 books on the war in print. The Royal Mail has issued "classic, prestige and presentation" packs on the war that "enable you to enjoy both the stories and the stamps". Enjoy?! ${ }^{10}$ 
The French Great War historian, Nicolas Offenstadt has emphasized the importance, in twenty first century discourses about the First War, of three types of priorities: those of family history, of local pride and of activist approaches. ${ }^{11}$ In this article, after examining some of the national events, we will be looking in turn at each of these aspects, the activities they gave rise to, and some of the contradictions they may contain.

\section{National events}

\section{The Poppy Campaign}

10 The most visible of the nationwide commemoration activities is not one which has been set up for the centenary, but one which, with major vicissitudes, has been continuously present since the early 1920s. This is the Poppy Campaign, run by the Royal British Legion. It involves the wearing of a red paper flower, the "poppy of remembrance" in the weeks before November $11^{\text {th }}$, a symbol which is obtained in exchange for a donation to the Royal British Legion, a charity providing for the needs of soldiers and ex-soldiers from more recent conflicts. Until 1994, the centre of the poppy was inscribed "Haig Fund" after the controversial First World War general who first launched the charity. Since then, it has been inscribed simply "Poppy Appeal".

11 The political nature of the appeal is often denied. Nevertheless its founding by General Haig, the fact that, in 2014, serving soldiers are sent by their units to sell the poppies in public places, as well as the many advertising campaigns emphasizing the support of the poppy campaign for British troops presently in Afghanistan and elsewhere, show that its military patriotism cannot be considered as entirely neutral. Anti-war campaigner Lindsey German wrote in a column in The Independent:

Given that wars tend to be unpopular, the government and military try to recast appeals for war as support for individual troops. This is what lies behind the hugely increased profile of the Poppy Appeal in recent years. ${ }^{12}$

As the campaign posters shown below illustrate, the Royal British Legion presents the wearing of a poppy as a patriotic duty, but also as a moral duty of solidarity, a "commonsense" humanitarian decision for everyone. This view is extremely influential among the UK population.

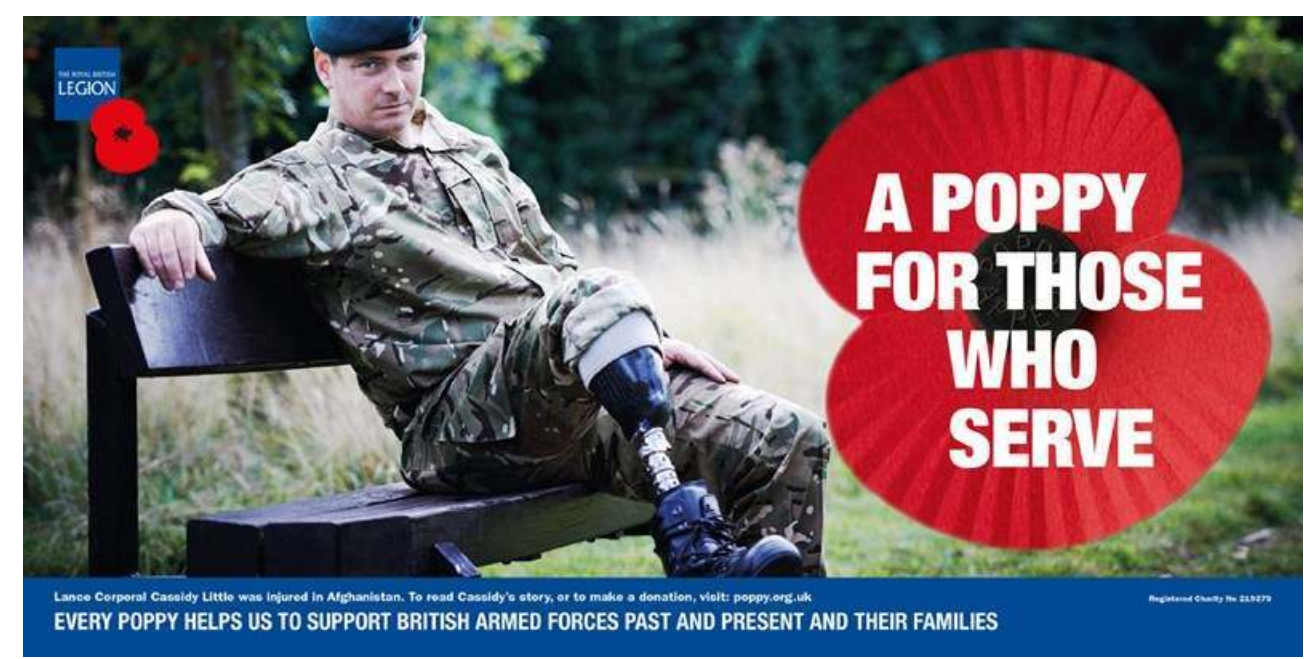

2013 CAMPAIgN 


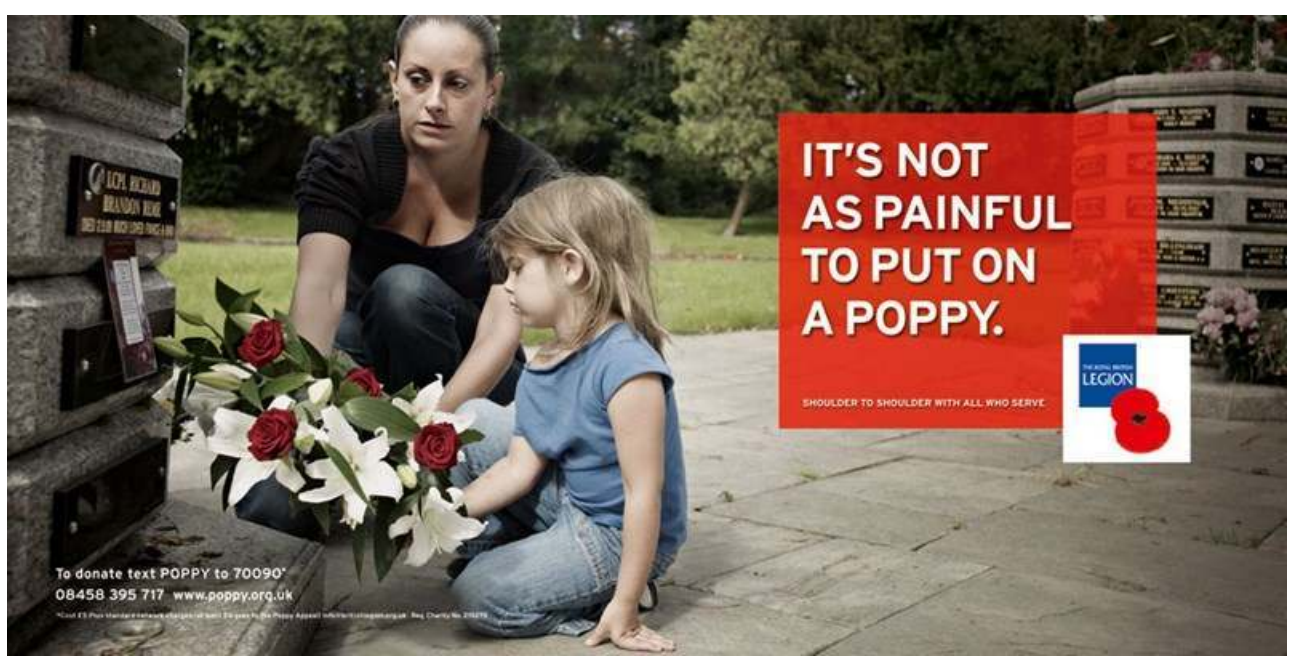

2010 CAMPAIgN

13 The campaign in 2014 was similar to, if grander than, those in previous years, and could involve considerable moral pressure. The mass circulation free daily newspaper, Metro, ran a headline in November "Should TV presenters lose their jobs if they refuse to wear a poppy while broadcasting?"13 The article explained that veteran presenter Jon Snow "refused" to wear a poppy on screen, although he was careful to point out that he did wear one in his private life. The tension is clear. One critic expressed the opinion that

[...] poppies have become less a symbol of genuine grief and recognition of the soldiers who have fallen fighting in our country's armed forces, and more a compulsory signifier that a person is on "our side". ${ }^{14}$

One group of the British population often suspected of not adhering to the priorities of British foreign policy was particularly under pressure. The conservative Daily Mail suggested it was not enough for Muslim women to wear a paper poppy like others, but that they should choose a more visible symbol: a hijab headscarf decorated with poppies. One of their headlines exclaimed: "The poppy hijab that defies the extremists: British Muslims are urged to wear headscarf as symbol of remembrance". ${ }^{15}$ It should be pointed out though, that this "hijab campaign" remained extremely marginal.

The Poppy Campaign and the denunciation of those who "refused" to wear a poppy were particularly visible in the world of football. Players from twenty clubs in the Premier League wore shirts emblazoned with a large remembrance poppy. West Ham United, for example, commemorated the centenary with a series of special events at their game in early November. Soldiers from local barracks marched ceremoniously onto the ground, a wreath was laid by local dignitaries and a minute's silence held before the match.

Individual footballers took risks if they did not wish to conform to this imposed consensus. James McClean of Wigan, who did not wear a poppy, was eventually pushed to write an open letter to his club's chairman justifying his decision. ${ }^{16}$ In Glasgow, sections of the Celtic supporters, generally seen as a Catholic or even republican milieu, were not willing to participate in the commemoration, and were roundly denounced for their dissent in the press:

YESTERDAY was a good day for Celtic on the pitch - but sadly the conduct of a section of the support overshadowed their gutsy win over Aberdeen.

On the $100^{\text {th }}$ anniversary of the outbreak of the First World War, it surely shouldn't be too much to ask for grown men to stand in silence for 60 seconds in respect of those who fell. Instead, a group of Hoops fans at Pittodrie chose to interrupt this 
simple act of remembrance and common decency - and the anger was clear in the messages sent to the Hotline's email inbox.

Chris Lowe, said: "Shameful but not surprising behaviour from Celtic as a football club in having no poppies on their jerseys for the game against Aberdeen. But not as shameful as the disgraceful behaviour of a small section of their support who yet again disrupted a minute's silence with pro-republican/anti-British chants." ${ }_{17}$

Not participating is presented as a question of immaturity, not worthy of "grown men", whereas the minute's silence is thought of as "common decency" and as obviously nonpolitical.

In this politicized context a series of initiatives have questioned the values of the red poppy campaign. The first is the "white poppy" campaign, which has existed for several decades as a small endeavour, but has gained more prominence in recent years. ${ }^{18}$ While defending the importance of commemoration, the white poppy campaign nevertheless contests the glorification of war which they see as frequent in remembrance events, and its sale is used to raise money for anti-war activities.

\section{The Tower of London}

The poppy campaign and the minute's silence, since they both involve an individual decision to consent and participate, caused more controversy than other national activities and events, which could be followed or ignored according to one's individual views.

One of the centrepieces of the commemoration, and a tremendously popular initiative, was the installation at the Tower of London. Entitled "Blood swept lands and seas of red", it included one (ceramic) poppy for every death in the First World War of British or Empire troops, almost 900,000 in all, put in place over the summer months by an army of unpaid volunteers. The poppies were subsequently sold to raise money for military charities. This spectacular work ${ }^{19}$ attracted millions of visitors, to such an extent that initial plans to completely dismantle the work were adapted, and a part of the installation will tour the country before being displayed at the Imperial War Museum in London. Paul Cummins and Tom Piper, the creators of the installation, were awarded an MBE by the queen in January 2015. ${ }^{20}$

21 Antimilitarists criticized the installation for estheticizing suffering, and a parody article about it circulated widely on social media, pretending the following:

In a moving tribute to British soldiers who died in WWI, all 888,246 hand-made poppies at the Tower of London exhibition have been mowed down by machine gun fire.

Tourists looked on, horrified, as a row of specially restored Maschinengewehr 08 machine guns were rolled into place along the embankments and started to obliterate the fragile ceramic flowers.

"This was always the plan," explained artist Tom Piper who helped to devise the exhibition. "Otherwise it would have just been some sort of mawkish display of nationalism. ${ }^{21}$

Other national events included a "lights out" initiative on August $4^{\text {th }}$, when every house in Britain was asked to switch off the lights between 10pm and 11pm. Organisers declared it was "one of the most dramatic UK-wide events ever organised" in which "people from all four nations will be invited to turn off their lights and to replace them with one single light to remember a day that changed the world forever". ${ }^{22}$ This lights out event was meant to echo the words 
said to have been pronounced by the British foreign secretary, Edward Grey, as the war broke out: "The lamps are going out all over Europe; we shall not see them lit again in our lifetime". ${ }^{23}$ These two examples - the Tower of London installation and the "lights out" initiative show a desire for the spectacular in commemorative activity.

Some of the commemorative events had, it must be said, less of a clear link to the history of a century ago. Plans were made, for example, to plant many thousands of trees to help with the environment at the same time as commemorating the First World War. The Woodland Trust, responsible for this project, explained:

At a time when our woodland cover is so low compared to other countries, planting trees now is more important than ever [...] As well as representing the enormous strength and bravery shown by the nation during the First World War, the trees that are planted during the course of the project will help strengthen our natural landscape, increasing its resilience to threats posed by pests and diseases. ${ }^{24}$

It might seem that the Woodland Trust was carrying out identical projects to those of previous years (planting trees) and that the World War One link was somewhat specious.

\section{Media and arts events}

The world of broadcasting was naturally keen to be at the centre of the commemoration, and each TV and radio channel produced a range of programmes. On the $\mathrm{BBC}$ website one could see, once more, a desire for the massive and spectacular:

The BBC's World War One Centenary season is unlike any other season the BBC has undertaken, not least because of its scale. With programming and events spanning the four years from 2014-2018, echoing the time-frame of World War One, it is the biggest and most ambitious pan-BBC project ever commissioned, with more than 2,500 hours of programming already planned across television, radio and online and across our international, national and local services. ${ }^{25}$

Artistic activities, generally funded from public money, were also frequent.

From a wood in Monmouthshire to the salt-marshes of Orford Ness, from Liverpool Docks to the Cathedral quarter of Belfast, from the site of the trials of conscientious objectors in Battersea to Worcester Cathedral, Glasgow's Merchant City and villages in Cornwall, artists across the UK will create new works in response to the events of the First World War. [...] Ranging widely from large-scale, free outdoor events to intimate, immersive theatre works, the programme including dance, installations, cartoons, a Late Night Prom, a major new choral commission, performances in care homes, live music, short films, poetry, photography and new works of literature. ${ }^{26}$

Artists mentioned in the same article included well-known cartoonist Ralph Steadman, folk singer Richard Thompson, actor and comic Stephen Fry and novelist Jeanette Winterson.

In Birmingham, to give one example, an army of 5,000 ice sculptures of soldiers, slowly melting in the sun, was set up as a commemoration of the $\operatorname{war}^{27}$ in Cheshire railway stations a tour of a musical show based on the songs of a century ago, and in the theatre one could see an adaptation of Dalton Trumbo's 1938 anti-war novel "Johnny Got His Gun". ${ }^{28}$ At least a dozen other plays about the war were premiered during 2014. 


\section{Commemorating everyone?} desire to widen the range of people being commemorated. Soldiers killed in battle have been the traditional subjects of war monuments, church or workplace plaques and so on. They are often presented as universally heroic, whatever the cause or circumstances of their deaths. Yet in the twenty first century, others are also to be remembered. Perhaps the most novel addition is that of those soldiers executed for cowardice or desertion by the British army. Family members of executed soldiers had long lobbied for a pardon, and, decade after decade, governments had replied that this was not legally possible or politically desirable. In 1998, the Defence secretary of the time declared that there was no basis in law for a posthumous pardon. ${ }^{29}$ Yet a complete U-turn was to come about in 2006, and a blanket pardon of all those executed was announced. This may have been partly due to a fear that detailed examination of individual cases in international law courts might have been politically embarrassing.

This pardon had been preceded by the establishment of a national monument to the executed, the "Blindfold and Alone" monument representing a young soldier blindfolded and awaiting the firing squad. ${ }^{30}$ This statue was placed in the National Memorial Arboretum, that is to say, at an official and legitimate location. The contradiction of honouring in the same location the executed and the military authorities ordering the execution seems to have been little commented upon. We shall see below that this type of contradiction is not uncommon in the centenary activities.

Other commemorative activities are also marked by this inclusive approach. The exhibition at the Imperial War Museum North, the Manchester annexe of the institution, concentrates on recreating "the streets" of 1914-1918, and not the trenches, which have always been the emblematic Great War places to remember and recount. The new London IWM galleries also present "Life at Home" as well as "Fighting Fronts". ${ }^{31}$

Labour's spokesman Dan Jarvis insisted on this perceived need to widen the commemoration.

[...] I strongly believe that if we want to properly commemorate the First World War, if we want to do justice to the memory of those who lived through it 100 years ago, then these commemorations cannot solely be about those who fought and died on the frontline.

We also have to remember the heroes on the home front: The miners, factory and railway workers who kept our country going, those who worked the land, and cared for the wounded. And the commemorations also have to be about how our country changed. ${ }^{32}$

This extremely wide extension of the subjects of commemoration might be considered to weaken its previous meaning.

Some have insisted that the slow progress which has been made concerning the histories of colonial peoples should be reflected in commemorations. In November 2002 the Memorial Gates were opened in London's Hyde Park. They were built to remember the people of the Indian sub-continent, Africa and the Caribbean who fought in both World Wars, thus implicitly recognizing their absence in previously constituted historical narratives. And in 2014, there was a campaign to award a bravery medal posthumously to the first ever Black officer of the British army, a footballer from Tottenham, who, it is 
alleged, would have received a medal if he had been white. This last campaign, however, remained very small.

Naturally, encouraged by public interest and by the availability of specific funds, the academic world has not been left behind, and very many events to mark the centenary, conferences in particular, were to be seen.

\section{Family history}

The "family history", current in commemorative activity is linked to the rapidly increasing interest in genealogy and family history evident over the last twenty years. Although not as established as in the United States, family history is a preoccupation and hobby of tens of thousands of British people. The rise of the internet is part of the cause, since it facilitates the searching for information about and communication with people across the world who might be distantly related to you. British bookshops are full of advice books on how to establish a family history, and a very popular TV show "Who do you think you are?" traces celebrity family history as well as giving tips to the general public. ${ }^{33}$

For 2014, many local newspapers have encouraged readers to send in stories of their ancestors from the time of the First World War. The Bristol Post, the Derby Telegraph and the Lancashire Evening Telegraph are typical. This last writes:

We want your family memories of First World War! The Lancashire Telegraph plans to tell the story of East Lancashire's Great War heroes and the life of the people left behind. If you have any stories about your grandfather or other family member in the war - of their heroism, experiences in the trenches, or how they coped when they returned home, we would like to hear from you. ${ }^{34}$

Whereas the Yorkshire Film Archive appeals for information about family members: With thanks to the Heritage Lottery Fund we have been able to undertake vital preservation work on [...] original nitrate films and create new digital masters so that we can now make these films available for everyone to see. They are not official films about the War, neither were they made as a collection. They are, quite simply, a random number of films, made by local film makers, to show in local communities, which have, over the years, found their way to the Yorkshire Film Archive. As part of the project, we are conducting research into these films in order to identify individual soldiers and civilians, with the aim of bringing their personal stories to life as part of an online exhibition, due to launch in early 2015. We want to find out why the films were made, who made them - and most importantly, who those people are - the regiments, soldiers, civilians, dignitaries, children - who have been captured on film and have survived to appear on our screens once again, 100 years later. ${ }^{35}$

The identification of specific stories relating to one's ancestors no doubt allows people to feel a link with the experience of past generations, and this is a powerful demand in a period in which "identity" is an important cultural and political preoccupation.

\section{Local pride}

Narratives of pride or attachment to localities constitute a second powerful strand running through commemoration activities. Local pride was no doubt even more important to people a century ago, when people moved far less between regions, and recruitment authorities recognized this when they created "Pals battalions", army 
groupings which allowed them to guarantee that volunteer soldiers would serve with men from their own town. This scheme helped recruitment, but deepened tragedy for many: fatalities in trench warfare are often concentrated in particular battalions, and this meant extreme losses for certain towns on particular days. The small town of Accrington in Lancashire ${ }^{36}$ is a case in point, since it lost 700 killed or wounded on the single morning of $1^{\text {st }}$ July 1916. For the centenary, a huge banner commemorating the Accrington Pals was raised in the town centre, while a local theatre group, the Oswaldtwistle Players, staged a theatre play about the battalion. This kind of commemoration was common elsewhere: in Liverpool a play, Echoes of the First World War was produced at St George's Hall.

\section{Activist discourses}

If family discourses and local pride discourses have both become more important in recent years, political or activist discourses about the First World War remain very potent. From the beginning of the year, it was clear that the commemoration could not be apolitical. As we mentioned above, Michael Gove, Conservative Secretary of State for Education weighed in in January with a much commented article in the Daily Mail.

Historian Max Hasting wrote in a similar vein:

We are witnessing a depressingly familiar spectacle. Political correctness has taken hold. Those planning the commemoration feel almost embarrassed that we won the war, and are determined to say and do nothing that might upset Germany, our modern EU partner. I can think of no greater betrayal than for the British Government [...] to pretend that they perished for nothing, because ignorant or frightened ministers flinch from upsetting today's Germans. ${ }^{37}$

We see here clearly the high emotional temperature which has accompanied debates about Empire policy and Empire "heroes" of a century ago. Mr Hastings maintains that ministers are "frightened" and considers alternative political visions of the Great War as nothing short of "betrayals". The First World War is no doubt the oldest event which provokes emotional reactions of this sort: one would have difficulty in imagining such exchanges concerning the Boer War or the Indian rebellion of 1857.

However, generally speaking, the "common sense" commemorations, presented as " apolitical," satisfied conservative opinion with the use of heroic vocabulary and imagery, and so the most visible activist discourses were those on the dissenting side. Indeed, the setting up of the "No Glory in War" campaign ensured significant coverage for dissenting activist voices. This campaign was established specifically to intervene around the Great War centenary. ${ }^{38}$

41 The campaign, an offshoot of the Stop the War Coalition, chose its name carefully so as to be able to federate a fairly wide body of opinion, without opposing directly the commemoration of the war, nor introducing an explicitly anti-imperialist analysis, despite the Marxist affiliations of its main initiators.. A series of celebrities such as poet laureate Carol Ann Duffy, rock singer Billy Bragg, cinema director Ken Loach and actor Jude Law were among those who signed the "No Glory" statement, as well as two members of parliament.

42 The No Glory campaign and website were able to respond throughout 2014 to different aspects of the debate about the war. So, when conservative historian Dan Snow wrote his article "Ten myths about World War One" ${ }^{39}$, No Glory countered with its "“Ten myths 
about World War One' answered". ${ }^{40} \mathrm{~A}$ wide debate ensued in the media. No Glory organized, in addition, several dozen meetings, debates and cultural events around the country, with titles such as "How Should We Remember World War One?" "Was World War One a War for Democracy?" and "Carving Up the Globe - the Real Causes of World War One". The organization was sufficiently well-thought of to be invited to a contradictory debate at the British Library, ${ }^{41}$ and to be able to co-organize with Manchester Centre for Regional History an "Alternative World War I Day School" in November.

At the other extreme of the scale from intellectual commemoration and debate to popular festival, perhaps, was the production of special local beers to commemorate the centenary. The three speciality beers, brewed by the small company Irwell in Lancashire, were somewhat flippantly named "Over The Top", "Lest We Forget" and "Lions Led by Donkeys $"{ }^{42}$ The exact intention, between nostalgia, commemoration and anti-militarist popular expression, is not easy to analyse.

\section{Oh What a Lovely war!}

The musical play Oh What a Lovely War, first produced in 1963 by Joan Littlewood's Theatre Workshop played an important part in cultural commemoration of the Great War in 2014. This work uses maudlin or patriotic music hall songs and cynical, bitter or demoralized soldiers' songs to structure a sarcastic critique of the First World War presented as a crime perpetrated by Europe's elites. It has been much denounced over the years by defenders of British policy in the Great War period. The different productions in 2014 have played more on the acerbic political critique side or more on the nostalgic side of this multifaceted work. The Theatre Royal Stratford, in its production, proclaimed loud and clear the anti-establishment politics of Joan Littlewood's original 1960s staging. Indeed, this version begins with a Pierrot clown describing a series of pre-war Bank holiday scenes, while a slide show projects images of the seaside, bathers, and a donkey. The "donkey" shown has the face of Education Secretary Michael Gove, who has been so outspoken defending British imperial aims of a century ago.

However, uses of this musical play are not as unambiguous as one might think. We spoke to the director of a local amateur production in the North East of England, who gave us his view:

I think people read into it what they are comfortable with. Our production is by a very cosy church hall society in a wealthy dormitory town. It would be hard to imagine a less radical group. We have been asked along to sing some of the songs at the towns Armistice Day ceremony and at an exhibition they are staging about WW1. I doubt they are really aware that this was a massively controversial piece of left-wing theatre, since time lends respectability. I think it's a measure of the original show's influence that it no longer seems controversial to see the Tommies as "lions led by donkeys". ${ }^{43}$

These different uses of stagings of the antimilitarist piece make on reflect on the extreme flexibility of such an object, when subjected to appropriations fifty years after it was written.

Other complexities can be found in uses of the play: the staging of the show may not have been as uncontroversial everywhere. In Derby, a production poster explained: "Tickets are priced $£ 6$, with $£ 1$ from each sale being donated between The British Legion and Help for Heroes". The choice of the charity "Help for Heroes", decidedly not an anti-war association may 
well have been intended to pre-empt criticism, while the decision to divide equally between two charities the very small amount of money involved strongly suggests that there were differences of opinion within the group.

Activist approaches ensured that a number of other antimilitarist commemorations were held. In London there was "A re-enactment of the anti-war meeting held outside the Salisbury pub 100 years ago, when the First World War broke out". The flyer explained:

Come and hear from some of the characters who spoke out then - men who went on to be conscientious objectors, suffragettes who opposed the war, working people who had no quarrel with workers from other countries. There will be short speeches from characters dressed as in 1914 with songs of the period sung by Patricia Hammond (mezzo-soprano) accompanied by Matt Redman (guitar, mandolin-banjo). ${ }^{44}$

Political activism is no doubt the major motivation for this event, but nostalgic music and singer virtuosity, it is emphasized, would also be part of the attraction.

\section{Commemorating the Christmas truce}

The last set of commemorative events we shall look at is perhaps the most complex. It is the various activities organized around the centenary of the famous "Christmas Truce". ${ }^{45}$ In fact this event was a series of twenty or more truces, generally initiated by German troops $^{46}$ and involving a very large number of soldiers. These were acts of insubordination, and although the widespread nature of the truce meant that few were punished in 1914, those who tried to repeat the experience the following year were sometimes court-martialled and imprisoned. Celebrating such a rebellion might easily be thought to be the reserve of anti-war activists, or even anti-army activists. In the event, the commemoration was taken up widely by establishment figures and institutions, with little comment on the contradictions involved.

Events commemorating the truce included simultaneous street art events in London and Berlin organized "in the spirit of promoting ongoing peace". There was also a "Christmas Truce centenary party" on December $20^{\text {th }}$ :

It will be opened by football writer and spoken word artist Musa Okwonga debuting a specially-written poem to honour Walter Tull, one of the first Black British footballers (a commissioned officer in the British Army, killed on active service in 1918). Comic genius Kate Smurthwaite will be offering her own particular interpretation of the meaning of Lord Kitchener's infamous recruiting poster "Your Country Needs You". ${ }^{47}$

The inclusion of football in the commemoration is due to the widely reported and unsurprising fact that one of the joint activities of British and German soldiers during the truce was playing football.

A memorial to the truce (designed by a schoolboy after a nationwide competition) was dedicated in December 2014 at the National Memorial Arboretum by the Duke of Cambridge, accompanied by the manager of the English national football team. ${ }^{48}$ The Duke of Cambridge, Prince William, is second in line to the British throne, and is an officer in the Royal Air Force, so his official celebration of military insubordination might be seen as the most extreme case of the appropriation of antimilitarist symbols. The Prince commented: 
Football had the power to bring people together and break down barriers. It is vital that 100 years on we keep the Christmas truce story alive. For future generations this memorial will help ensure that not just football, but also a nation, remembers. ${ }^{49}$ of the Christmas truce. The supermarket chain, Sainsbury's, produced its official Christmas advertisement in cooperation with the Royal British Legion. This is a four minute sentimental film of the truce, with just at the very end the slogan "Christmas is for sharing: Sainsbury's". ${ }^{50}$

advert was generally well received, showing the complexity of public reactions built on nostalgia, popular antimilitarism and no doubt other elements too. It did however, come in for some criticism. Ally Fogg in The Guardian rites "In making the first world war beautiful to flog groceries the film-makers have disrespected the millions who suffered in the trenches", ${ }^{51}$ whereas the No Glory campaign awarded the advert its prize for "most cynical exploitation of world war one for commercial gain."

\section{Conclusions}

Commemoration is a complex social activity, which can in no way be reduced to nostalgia or to populist nationalism. The commemorative activities in the UK in 2014 showed a remarkable capacity of people, organizations and institutions to use the First World War to express their current priorities, both explicit and implicit. Ambiguity was central: activities which could be interpreted as either patriotic or respectful of the dead or antiwar were naturally able to drain huge audiences. More work could certainly be done on the meanings of nostalgia and commemoration in Britain and the link between the two. In addition, the activities in other countries, in Commonwealth countries in particular, would merit closer attention.

\section{BIBLIOGRAPHY}

Brown, Malcolm and Seaton, Shirley, Christmas Truce, London, Pan Books, 1994

Offenstadt, Nicolas, 14-18 Aujourd'hui, La Grande Guerre dans la France Contemporaine, Paris, Odile

Jacob, 2010

\section{Periodicals}

National daily newspapers

Daily Mail

The Scotsman

The Guardian

Daily Telegraph

The Independent 
Metro

Daily Record

Local newspapers

North London Star

Derby Telegraph

Lancashire Evening Telegraph

Bristol Mail

Birmingham Mail

\section{Websites}

Yorkshire Film Archive www.yorkshirefilmarchive.com

Official Irish government website for the centenary www.decadeofcentenaries.com

Website of Labour party spokesman on the centenary commemorations www.danjarvismp.co.uk

Stop the War Movement http://stopwar.org.uk

British Broadcasting Corporation www.bbc.co.uk

Imperial War Museum www.iwm.org.uk/

No Glory in War" campaign http://noglory.org/

Flanders Tourism website www.visitflanders.co.uk

\section{NOTES}

1. BBC News, February 16, 2003, http://news.bbc.co.uk/2/hi/uk_news/2765041.stm (accessed March 13, 2015).

2. http://www.stopwar.org.uk/ (accessed March 13, 2015).

3. See for example Oxford history professor Margaret Macmillan in The Guardian, January 10, 2014.

4. Daily Mail January 3, 2014.

5. http://www.danjarvismp.co.uk/news/speeches-articles/labour-the-first-world-war (accessed December 28, 2014).

6. http://www.scotsman.com/news/politics/top-stories/clash-between-wwi-and-bannockburnmemorials-feared-1-2912362 (accessed December 28 2014).

7. For non-francophone readers: "Poilus" - literally "the hairy ones" was the nickname given to French soldiers of the Great War.

8. Daily Telegraph March 52014.

9. BBC News November 112014

10. The Guardian August 42014.

11. Nicolas Offenstadt, 14-18 Aujourd'hui, La Grande Guerre dans la France Contemporaine, Paris, Odile Jacob, 2010.

12. The Independent October 23, 2014.

13. Metro, November 6, 2014.

14. http://stopwar.org.uk/news/refusing-to-wear-the-poppy-hijab-doesn-t-make-me-anextremist-muslim

15. Daily Mail, October 30, 2014. 
16. The Guardian November 7, 2014.

17. Daily Record November 102014.

18. http://www.ppu.org.uk/whitepoppy/

19. See the illustrations appendix in this issue of our journal.

20. BBC News, December 31, 2014. http://www.bbc.com/news/uk-england-derbyshire-30626494 (accessed March 13, 2015)

21. http://undergroundmgzn.com/2014/11/11/tower-london-poppies-obliterated-machineguns/ (accessed March 13,2015).

22. Daily Telegraph July 4, 2014.

23. Ibid.

24. The Independent March 112014.

25. http://www.bbc.co.uk/mediacentre/mediapacks/ww1/

26. Heritage Lottery Fund press release March 27, 2014. https://www.hlf.org.uk/about-us/mediacentre/press-releases/lights-out-contemporary-artists-throw-new-light-first-world-war

27. Birmingham Mail September 10, 2014.

28. www.southwarkplayhouse.co.uk (consulted February 23 2015).

29. BBC history website, «Shot at Dawn». http://www.bbc.co.uk/history/british/ britain_wwone/shot_at_dawn_01.shtml (accessed March 13, 2015).

30. See the appendix of illustrations.

31. http://www.iwm.org.uk/ (accessed March 13, 2015).

32. http://www.danjarvismp.co.uk/news/speeches-articles/labour-the-first-world-war (accessed December 28, 2014)

33. http://www.bbc.co.uk/programmes/b007t575

34. Lancashire Evening Telegraph, April 22014.

35. http://www.yorkshirefilmarchive.com/videos/filmed-and-not-forgotten (accessed March 13,2015).

36. In fact, the home town of the present writer.

37. Daily Mail June 112013.

38. http://noglory.org (consulted February 23 2015).

39. http://www.bbc.com/news/magazine-25776836 (accessed January 15 2015)

40. http://noglory.org/index.php/articles/112-lions-and-donkeys-dan-snow-s-10-myths-aboutworld-war-one-answered-by-no-glory\#.Ut44CftKFko (accessed January 15, 2015)

41. This debate can be sen on line at https://www.youtube.com/watch?v=AhcmlsAvN8E (accessed January 27, 2015).

42. See appendix of illustrations.

43. Interview with Jonathan Cash, November 2014.

44. North London Star, July 29, 2014.

45. For a full account see Malcolm Brown and Shirley Seaton, Christmas Truce, London, Pan Books, 1994.

46. There wer two reasons for the Germans being the initiators : firstly far more German soldiers spoke English than the reverse; secondly, German Christmas celebrations empasize the 24th of December, and British celebrations the $25 \mathrm{th}$, so the Germans were the first who were ready to celebrate.

47. http://www.visitflanders.co.uk/discover/flanders-fields-/the-christmas-truce-in-flandersfields/index.jsp (accessed March 13, 2015).

48. BBC News December 12, 2014.

49. Ibid.

50. https://www.youtube.com/watch?v=NWF2JBb1bvM (accessed March 13, 2015).

51. The Guardian, November 13, 2014. 
AUTHOR

JOHN MULLEN

Université Paris-Est Crétéil 